\title{
Effect of Managers' Professional Efficiency on the Net Sale of Cooperative Union in Oromia Regional State, Ethiopia
}

\author{
Merga Futasa Begna \\ PhD-scholar at College of Business and Economics, Department of Cooperatives, Ambo University
}

\begin{abstract}
Wambua (2011) concludes that employee involvement affected the financial performance of the cooperatives. Develtere and Pollet (2004), conclude that in successful cooperatives, professional issues play a crucial role in harnessing the different associative and business forces at play in a cooperative. It is often inferred that agency problems are more prevalent, disturbing and acute in cooperatives than in other (non-investor owned) businesses. Therefore this study aims to assess the effect of professionalism on the net sale performance of cooperative unions. Research sample were 228 respondents of sampled from nine cooperative unions in oromia regional state, Ethiopia. Both primary and secondary data were collected and analysed using multiple regression model through SPSS. The result of the research concluded that there are significant influences of managers' professional efficiency variables on the net sale and there are also differences in the influence among the managers' professional related independent variables on the net sale of the selected cooperative union.
\end{abstract}

Keywords: Cooperatives, Net sale, Professionalism, Efficiency and Performance

DOI: $10.7176 / \mathrm{JAAS} / 77-02$

Publication date: January $31^{\text {st }} 2022$

\section{Introduction}

According to Homayara L.et.al., (2008) given the very large volume of business that agribusiness cooperatives in India handle and given the tough competition that they now face in the wake of large scale entry of domestic and foreign companies in the agribusiness sector in the country after the launching of New Economic Policy, it is essential for the survival and growth of agribusiness cooperatives that they are professionally managed. Mobilizing funds for diversification and modernizing of operations, management of funds, procurement of produce of members in small quantities from remote rural areas, processing the produce using the latest technologies available, exploring and tapping new markets for inputs and outputs, marketing of products at competitive prices in a free market regime, ensuring high quality of products, keeping production and other operating costs under control, attracting and retaining good staff, securing and using right information at right time for making decisions activities require professional managers to handle them efficiently. In the twenty-first century, it will be the manager's knowledge, foresights, insights, management skills, and ability to access and use the right information at the right time for making various decisions that will determine the prospects of survival and growth of business enterprises. Therefore, agribusiness cooperatives will have to professionalise their management and sooner they do so, the better it is for them. In the absence of professional management, money, manpower and material resources of agribusiness cooperatives worth thousands of resources are wasted annually. Liu et al, (2015) showed positive effect between professionalism and performance and performance difference between professional and unprofessional people. This motivated the researcher to conduct a research on the effect of managers' professional efficiency on net sale of cooperative union in Oromia region,Ethiopia.

\section{Statement of Problem of the Study}

According to MOCDM (2008), there exist opportunities for mismanagement namely: Insufficient commitment by stakeholders, insufficient clarity of roles and responsibilities by stakeholders, inadequate professionalism and discipline, inadequate internal management and operational system, elections are not free and fair and inadequate management committee education. Successful cooperatives are results oriented and creative with marketable products. They invest in quality management, and their pricing as well as interest rate policies are inspired by the prevailing market conditions (Develtere et al, 2008: 20). Research related to auditor professionals with the auditor's performance has been studied by many researchers before, but research has been more directed to the professionalism influence on the performance of auditors (Nasrabadia and Arbabian, 2015; ) But not much to examine whether there are differences in the effect on the performance of the auditor's professionalism among men and women auditors. To fill this gap the researcher conducted this research on this area.

\subsection{Objective of the study}

-To study the effect of managers' professional efficiency on the net sale of cooperative union in Oromia region,Ethiopia. 


\section{Hypothesis}

Ho: Managers' professional efficiency in the cooperative has no significant effect on net sale of cooperatives union in Oromia regional state, Ethiopia.

H1: Managers' professional efficiency in the cooperative has significant effect on net sale of cooperatives union in the Oromia regional state, Ethiopia.

\section{Research Methods}

\subsubsection{Research design}

Co-relational design will enable the researcher to map out the effect of professionals efficiency and governance of cooperative on business performance of cooperatives.

\subsubsection{Samples}

The research sample is determined by purposive sampling counted 228 respondents sample from cooperative union employees. Data were collected from both primary and secondary sources. Analysed using multiple regression model through SPSS.

Research Results And Discussion

\begin{tabular}{|c|c|c|c|c|c|c|c|c|c|c|}
\hline \multirow[t]{2}{*}{ Model } & \multirow[t]{2}{*}{$\mathrm{R}$} & \multirow{2}{*}{$\begin{array}{c}\mathrm{R} \\
\text { Square }\end{array}$} & \multirow{2}{*}{$\begin{array}{l}\text { Adjusted R } \\
\text { Square }\end{array}$} & \multirow{2}{*}{\multicolumn{3}{|c|}{ Std. Error of the Estimate }} & \multicolumn{4}{|c|}{ Change Statistics } \\
\hline & & & & & & & df1 & $\mathrm{df} 2$ & \multicolumn{2}{|c|}{ Sig. F Change } \\
\hline 1 & $.89^{\mathrm{a}}$ & .7921 & .001 & & & 390343367 & 8 & 21 & & .003 \\
\hline \multicolumn{11}{|c|}{ ANOVA $^{a}$} \\
\hline Model & & & Sum of Squares & & $\mathrm{df}$ & \multicolumn{3}{|c|}{ Mean Square } & $\mathrm{F}$ & Sig. \\
\hline \multirow{3}{*}{1} & \multirow{2}{*}{\multicolumn{2}{|c|}{$\begin{array}{l}\text { Regression } \\
\text { Residual }\end{array}$}} & \multicolumn{2}{|c|}{1242056177604829440} & 8 & \multirow{3}{*}{\multicolumn{3}{|c|}{$\begin{array}{l}155257022200603584 \\
152367944471240704\end{array}$}} & 1.019 & $.003^{\mathrm{b}}$ \\
\hline & & & \multirow{2}{*}{\multicolumn{2}{|c|}{$\begin{array}{l}33368579839201735000 \\
34610636016806564000\end{array}$}} & 219 & & & & & \\
\hline & \multicolumn{2}{|c|}{$\begin{array}{l}\text { Residual } \\
\text { Total }\end{array}$} & & & 227 & & & & & \\
\hline
\end{tabular}

a. Dependent Variable: NETSALES

b. Predictors: (Constant), Technical skill, Teaming skill, Motivational skill, Communication skill, Leading skill, Decision making Skill, Conflict Resolution skill, Staff Maintenance Skill

Source : Computed from Survey Data(2020)

Table 4.16 : Coefficients ${ }^{\mathrm{a}}$

\begin{tabular}{l|r|r|r|r|r}
\hline \multirow{2}{*}{ Model } & \multicolumn{2}{|c|}{ Unstandardized Coefficients } & Standardized Coefficients & \multirow{2}{*}{$\mathrm{t}$} & \multirow{2}{*}{ Sig. } \\
\cline { 2 - 5 } & \multicolumn{1}{|c|}{$\mathrm{B}$} & \multicolumn{1}{c|}{ Std. Error } & Beta & & \\
\hline (Constant) & 1118994629.497 & 235789095.452 & & 4.746 & .000 \\
Technical skill & 14179471 & 31397886.637 & .038 & .452 & .050 \\
Teaming skill & 16492546 & 34496280.450 & .049 & .478 & .033 \\
Motivational skill & 14351755 & 34264954.566 & .047 & .419 & .007 \\
Communication skill & -94304569 & 41354440.178 & -.218 & -2.280 & .024 \\
Leading skill & 22255606.977 & 29890352.724 & .068 & .745 & .0057 \\
Decision making Skill & 3824154.636 & 30829401.114 & .009 & .124 & .002 \\
Conflict Resolution skill & 50487001.491 & 43118166.607 & .086 & 1.171 & .043 \\
Staff Maintenance Skill & 17863851.219 & 62364142.783 & .021 & .286 & .000 \\
\hline
\end{tabular}

a. Dependent Variable: Net sale

Source : Computed from Survey Data(2020)

The result indicated table 4. 16 Above, all the variables which were included in the model have found significant effect on cooperative business performance (net sale) at 0.05 .

Technical Skill: the findings from Table 4.16 above, indicated that managers' technical skills has positive statistically significant effect on the business performance measured in net sale of the cooperative union $(\beta=$ $14179471 ; \mathrm{t}$-value $=0.452$ and $\mathrm{p}$-value $0.050=0.05$ ). From this result one can conclude that, one unit increase in managers' technical skill increases the business performance measured in net sale of the cooperative union by $14,179,471$ units.

Teaming Skill: the findings from Table 4.16 above, indicated that managers' teaming skills has positive statistically significant effect on the business performance (net sale) of the cooperative union $\beta=16492546$; $t$ value $=0.478$ and $p$-value $0.033<0.05)$. This result implies that, one unit increase in managers 'teaming skill increases the business performance (net sale) of the cooperative union by 16492546 units.

Motivational Skill: the result from Table 4.16 above, indicated that managers' motivational skills has positive 
statistically significant effect on the business performance (net sale) of the cooperative union $(\beta=14351755$; $\mathrm{t}$ value $=0.419$ and $p$-value $0.007<0.05$ ). From this result one can conclude that, one unit increase in managers' motivational skill increases the business performance of the cooperative union by 14351755 units.

Communication Skill: the output from Table 4.16 above, indicated that managers' communication skill has negative statistically significant effect on the business performance (net sale ) of the cooperative union $(\beta=$ 94304569; $\mathrm{t}$-value $=-2.280$ and $\mathrm{p}<0.024<0.05$ ). From this result one can conclude that, one unit change in managers' communication skill with boards, members and other stakeholders of the unions changes the business performance(net sale) of the cooperative union by -94304569 units.

Leading Skill: as evident from the output from Table 4.16 above, indicated that managers' leading skills has positively statistically significant effect on the business performance (net sale) of the cooperative union $(\beta=$ 22255606 ; $\mathrm{t}$-value $=0.745$ and $\mathrm{p}<0.0057<0.05$ ). From this result one can conclude that, one unit raise in managers' leading skill of the business activities raises the business performance(net sale) of the cooperative union by 22255606 units.

Decision Making Skill : Table 4.16 above, indicated that managers' decision making skill has positively statistically significant effect on the business performance (net sale) of the cooperative union $(\beta=3824154 ; \mathrm{t}$ value $=0.009$ and $p<0.002<0.05$ ). The result indicates that, one unit increase in managers' decision making skill in the unions increases the business performance (net sale) of the cooperative union by -3824154 units.

Conflict resolution Skill: the indicated result in Table 4.16 above, indicated that managers' Conflict resolution Skill has positively statistically significant effect on the business performance (net sale) of the cooperative union $(\beta=50487001 ; \mathrm{t}$-value $=1.171$ and $\mathrm{p}<0.043<0.05)$. From this result one can conclude that, one unit move up in managers' conflict resolution skill concerning the leadership and business issues of the unions' moves up the business performance (net sale) of the cooperative union by 50487001 units.

Staff Maintenance Skill: as the result shown in Table 4.16 above, indicated that managers' staff maintenance skill has positively statistically significant effect on the business performance (net sale) of the cooperative union $(\beta=17863851 ; t$-value $=-0.286$ and $p<0.000<0.001)$. From this result one can conclude that, one unit change in managers' staff maintenance skill with boards, members and other stakeholders of the unions changes the business performance(net sale) of the cooperative union by -17863851 units.

\section{Conclusion}

From the findings of the research one can concluded that there are significant effect of managers' professional efficiency variables on the net sale and there are also differences in the influence among the managers' professional related independent variables on the net sale of the selected cooperative union in the study area.

\section{References}

Develtere P., Pollet I, and Wanyama F., (2008). Cooperating out of Poverty: The Renaissance of the African Cooperative Movement, Geneva.

Homayara Latifa Ahmed, Md. Jahangir Alam, Saeed Alamgir Jafar, Sawlat Hilmi Zaman Conceptual Review on Corporate Governance and its Effect on Firm's Performance: Bangladesh Perspective. AIUB Bus Econ Working Paper Series

Liu, G., Yu, X., Cheng, X . 2015. The Effects of Professional Managers' Credit on Their Work Performance: Firm Owners' Trust and Credit Identification Mechanisms. Frontiers of Business Research in China. 2015, Vol. 9 Issue 2, p192-206. 15p

MOCDM (2008). Corporate governance report,Nairobi,Vas consultants, Ltd.

Nasrabadia, A., Arbabian, A. 2015. The effects of professional ethics and commitment on audit quality. Management Science Letters 5: 1023-1028

Wambua K.P, (2011). Effect of savings and credit cooperatives 'financial performance in Kenya, Unpublished Thesis, KCA University. 